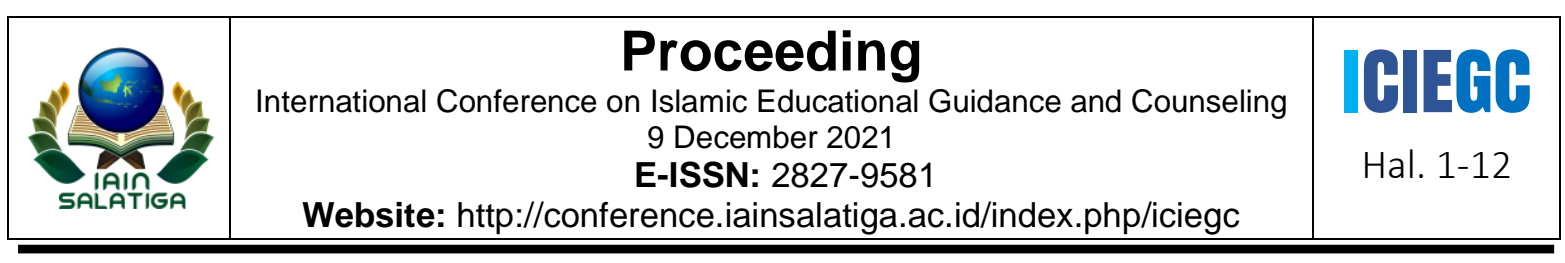

\title{
PROBLEMATIKA KONSELING MULTIKULTURAL PADA PELAKSANAN BIMBINGAN KONSELING DI SMP NEGERI 8 REJANG LEBONG
}

\author{
Desty Kurniaty $^{1}$, Aji Prayetno ${ }^{2}$, Yefni Novalia ${ }^{3}$ Hartini $^{4}$ \\ ${ }^{1}$ SMPN 1 rejang Lebong \\ ${ }^{2}$ MA Muhammadiyah Curup \\ ${ }^{3}$ SMPN B Srikaton \\ ${ }^{4}$ Pascasarjana IAIN Curup
}

\begin{tabular}{l}
\hline Informasi Artikel \\
\hline Penulis Korespondensi: \\
Aji Prayetno, \\
Email: \\
ajiprayetno0@gmail.com
\end{tabular}

\begin{abstract}
The importance of multiculturalism counseling because through this personal social guidance individuals can learn to adapt, understand the culture in different environments, and the diversity of cultures that exist. This study discusses the Problems of Multicultural Counseling Case Studies of SMP Negeri 8 Rejang Lebong ". Meanwhile, this type of data uses primary and secondary data with data collection through interviews, observation and documentation. In addition, the data analysis technique used data reduction, data presentation and data verification and continued with checking the validity of the data. The results of the study, namely the form of Problems for students of SMP Negeri 8 Rejang Lebong, are as follows: The difficulty of counselors offering multicultural counseling must be in accordance with the counselee's culture because the reality of the multicultural environment of students becomes a problem for counselors The obstacles in implementing multicultural counseling are: lack of parental cooperation with problem students and lack of participation between teachers and students, cultural differences in students that require BK teachers to understand different student cultures and limited counseling room facilities. Efforts in dealing with multicultural problems are carried out by increasing the implementation of multicultural counseling, increasing collaboration with teachers, parents and utilizing media in multicultural counseling and providing guidance on character values based on religion.
\end{abstract}

\begin{tabular}{l}
\hline Keyword: Multicultural counseling; counseling; guidance \\
\hline ABSTRAK \\
\hline Pentingnya konseling multikulturalisme adalah karena melalui \\
bimbingan ini pribadi sosial individu dapat belajar menyesuaikan \\
diri, paham terhadap budaya di lingkungan yang berbeda, dan \\
keragaman budaya yang ada. Penelitian ini membahas tentang \\
Problematika Konseling Multikultural di SMP Negeri 8 Rejang \\
Lebong". Sementara itu jenis data menggunakan data primer dan \\
sekunder dengan pengumpulan data melalui wawancara, observasi \\
dan dokumentasi. Selain itu teknik analisis data menggunakan \\
reduksi data, penyajian data dan verifikasi data dan dilanjutkan \\
dengan pengecekan keabsahan data. Hasil penelitian yaitu bentuk \\
Problem Siswa di SMP Negeri 8 Rejang Lebong diantaranya sebagai \\
berikut: Kesulian konselor menawarkan konseling multikultural \\
harus benar-benar sesuai dengan budaya konseli karena realitas \\
\hline
\end{tabular}


lingkungan siswa yang multikultur menjadi problem bagi konselor. Kendala-kendala dalam melaksanakan konseling multikultural yaitu: kurangnya kerjasama orang tua terhadap siswa bermasalah dan kurangnya partisipasi antar guru dengan siswa, adanya perbedaan budaya pada siswa yang mengharuskan guru BK memahami budayabudaya siswa yang berbeda-beda dan terbatasnya sarana ruangan konseling. Upaya dalam menangani problematika multikultural dilakukan dengan cara meningkatkan pelaksanaan konseling multikultural, meningkatkan kerjasama dengan guru, orangtua dan memanfaatkan media dalam konseling multikultural dan memberikan bimbingan nilai-nilai karakter berdasarkan agama.

Kata kunci: Konseling Multikultur; Konseling; Bimbingan.

\section{PENDAHULUAN}

Pada hakikatnya manusia sebagai makhluk sosial dan budaya, tidak terlepas dari dua unsur yaitu sosial dan budaya karena manusia terlahir sebagai makhluk sosial yang berbudaya. Kebudayaan manusia memiliki pengaruh yang besar terhadap sikap, perilaku, dan sudut pandang seseorang. Oleh karena itu manusia membutuhkan bimbingan untuk mempercayai hal tersebut. Bimbingan ditunjukan kepada perkembangan pribadi setiap orang baik menyangkut aspek akademik, sosial dan pribadi. Bimbingan dan konseling dilaksanakan dengan landasan semangat Bhineka Tunggal Ika, yaitu kesamaan di atas keragaman. Seperti yang dijelaskan dalam Surat Al-Hujarat ayat 13 yaitu sebagai berikut:

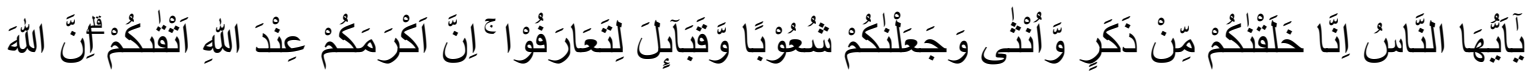
عَلِيْمُ خَبْيِرْ

Artinya :

Hai manusia, Sesungguhnya Kami menciptakan kamu dari seorang laki-laki dan seorang perempuan dan menjadikan kamu berbangsa-bangsa dan bersuku-suku supaya kamu saling kenal-mengenal. Sesungguhnya orang yang paling mulia diantara kamu disisi Allah ialah orang yang paling taqwa diantara kamu. Sesungguhnya Allah Maha mengetahui lagi Maha Mengenal.

Selain dalam ayat Al-Qur'an, telah diisyaratkan oleh ajaran Islam (Hadits) agar berdiskusi, berinteraksi, dan berkomunikasi sesuai dengan kadar/kemampuan akal individu atau komunitas masyarakat itu sendiri, seperti hadist yang artinya:

"Al-'Uqaili berkata: Diceritakan kepada kami 'Ubaidillah bin Muhammad AlKasyu'riberkata: telah menceritakan kepada kami Muhammad bin Yahya bin Jamil, telah menceritakan kepada kami Bakar bin Al-Syar'ud, telah menceritakan kepada kami Yahya bin Malik bin Anas, dari ayahnya dari AlZuhri dari Sa 'id bin Al-Musayyib berkata: Rasulullah SAW. bersabda: kami para Nabi juga 
diperintahkan kepada kami untuk berbicara dengan orang sesuai dengan kadar akal mereka. “

Berdasarkan hadist tersebut dapat dipahami bahwa konselor sedapat mungkin memahami kultur orang lain dan jika tidak maka itulah yang akan menjadi hambatan dalam konseling lintas budaya atau crooss culture. Konflik yang terjadi disebabkan oleh tidak adanya pemahaman individu terhadap orang lain atau kelompok satu dengan kelompok lainnya. Bahkan terkadang diikuti dengan pemaksaan atas pemahaman yang dimilikinya bagi masyarakat lain. Ajaran Islam telah cukup jelas bagi manusia bahwa tidak berlaku pemaksaan bagi orang lain. Baik dari aspek aqidah/ agama maupun aspek ras, etnis dan adat istiadat dan budaya.

Layanan dasar bimbingan konseling adalah layanan bimbingan yang bertujuan untuk membantu seluruh siswa mengembangkan prilaku efektifan keterampilan-keterampilan hidupnya yang mengacu padaa tugas-tugas perkembangan siswa (Wibowo, 2015). Bimbingan dan konseling di sekolah dilakukan oleh seorang guru (konselor), guru didalam sekolah tidak hanya mentranfer pengetahuan kepada siswa-siswa. Guru juga sebagai pelopor untuk menciptakan orang-orang berbudaya, berbudi dan bermoral. Keefektifan konseling bergantung pada banyak faktor yang terpenting adalah relasi satu sama lain, dan saling mengerti antara konselor dan klien. Perbedaan budaya yang ada di tanah air menuntut konselor perlu memahami berbagai kebudayaan yang ada. Pentingnya multikultural bagi konselor sebagai bentuk kesadaran bahwa konselor dan klien memiliki perbedaan budaya (Elizar, 2018).

SMP Negeri 8 Rejang Lebong adalah salah satu lembaga sekolah Negeri yang memiliki siswa dengan latar belakang suku yang berbeda-beda antara lain suku Jawa, Melayu, Sunda, Batak dan Minang. Perbedaan suku dan latar belakang siswa ini mengakibatkan berbagai perilaku dan budaya siswa yang berbeda-beda karena siswa memiliki tatanan perilaku dari orang tua dan lingkungan yang berbeda-beda, berdasarkan observasi penulis, terlihat siswa yang masih memiliki budaya dan perilaku-perilaku yang erat kaitannya dengan adat budaya yang dianutnya kurang sesuai dengan norma, etika dan akhlak sehingga hal tersebut menjadi salah satu problem yang disebabkan oleh perbedaan antara konselor dan konseli karena setiap budaya memiliki pemaknaan persepsi yang berbeda atau tidak sama. Salah satu bentuk ketidak sesuaian norma, etika dan akhlak yang dilakukan oleh siswa seperti cara bersikap, berbicara dan bertingkah laku di sekolah yang masih mencerminkan sikap kurang sopan. 
Terlihat beberapa siswa yang memiliki adat istiadat ataupun budaya yang kurang positif dalam berbudaya, bersikap dan berakhlak seperti cara berkomunikasi dengan konselor yang kurang sopan, bersikap cuek kepada konselor serta kurang mengindahkan saran atau nasehat konselor, hal ini bisa terjadi salah satu penyebabnya yaitu adanya pembiasaan atas budaya yang telah diterapkan dalam keluarga dan lingkungannya. Latar belakang budaya yang berbeda antara konselor dan konseli akan berdampak pada perbedaan dan penerimaan makna dari apa yang disampaikan atau pun apa yang ditampilkan konseli maupun konselor saat berkomunikasi.

Selain itu, keadaan objek penelitian yaitu siswa SMP Negeri 8 Rejang Lebong belum seluruhnya terbiasa dengan budaya-budaya ataupun perilaku, akhlak dan sikap yang mencerminkan budaya religius. Permasalahan ini dikarenakan kurangnya keberhasilan orang tua dalam menanamkan nilai-nilai bagi pembentukan kepribadian dan watak siswa seperti membimbing, mendidik dan mengarahkan dengan bentuk prilaku, sikap dan tindakan yang sesuai dengan ajaran agamanya. Masih kurangnya pengajaran, pengamalan, dan pembiasaan serta pengalaman sehari-hari yang dialami siswa baik di lingkungan keluarga maupun di lingkungan masyarakat mengakibatkan siswa terbiasa bersikap, berakhlak dan melakukan perbuatan tindakan yang tidak sesuai dengan budaya luhur atau tidak sesuai dengan norma agama (Hartini, 2017). Hal ini terjadi karena terdapat keterpaduan, konsistensi, dan sinkronisasi antara nilai-nilai yang diterima anak dari pengajaran yang diberikan oleh orang tua dengan dorongan untuk pengamalan nilai-nilai tersebut ke dalam bentuk sikap, akhlak, tindakan dan perilaku nyata sehari-hari.

Selain itu berdasarkan pengamatan awal penulis di SMP Negeri 8 Rejang Lebong, masih kurangnya pembiasaan perilaku positif oleh orang tua dan keluarga dalam kehidupan sehari-hari yang sejalan dengan nilai-nilai agama yang diajarkan dan yang berlangsung secara terus menerus yang akan menciptakan suatu lingkungan yang melahirkan pribadipribadi anak yang utuh masih belum dilaksanakan dengan maksimal. Padahal semestinya di lingkungan keluarga, anak mendapatkan iklim ataupun suasana yang religius, akibat dari kurang kondusifnya lingkungan keluarga dan peran orang tua sehingga menyebabkan perilaku-perilaku anak yang menyimpang seperti adanya pergaulan bebas, kurangnya sikap sopan santun anak terhadap guru, orang tua dan antar sesama, terbiasa berkomunikasi tidak senonoh dan sebagainya. 


\section{METODE}

Penelitian ini menggunakan jenis penelitian studi pustaka (Library Reseach). Studi pustaka ialah penelitian yang teknik pengumpulan datanya dilakukan di lapangan (perpustakaan) dengan didasarkan atas pembacaan-pembacaan terhadap beberapa literatur yang memiliki informasi serta memiliki relevansi dengan topik penelitian (Sukardi, 2010). Serta observasi, wawancara, serta studi dokumentasi. Setelah itu informasi tersebut direduksi, didisplay serta disajikan sesuai dengan prosedur penelitian. Pendekatannya menggunakan berbagai studi literatur. Sastra yang digunakan adalah jurnal dan buku yang mendukung pengembangan gagasan tentang problematika konseling multikultural pada pelaksanan bimbingan konseling (Winarlin, dkk., 2016). Peneliti menyusun kerangka kerja konseptual problematika konseling multikultural pada pelaksanan bimbingan konseling (Lubis, dkk., 2017).

\section{HASIL DAN BAHASAN}

\section{Bentuk Problema Konseling Multikultural Pada Pelaksanaan Bimbingan Konseling di SMP Negeri 8 Rejang Lebong}

Multikulturalisme adalah keragaman dalam tema kebudayaan (Yamin, 2013) Multikuluralisme sebagai sebuah pandangan yang mengakui adanya perbedaan kelompok individu, memperkecil adanya perbedaan dalam kelompok, serta melihat dunia dengan berbagai aneka ragam budaya yang diciptakan masyarakat sehingga menjadi sebuah keunikan dan kekayaan bagi kehidupan individu (Firdaus, dkk., 2015).

1. Kurangnya Kerjasama Orang Tua terhadap Siswa Bermasalah

Apabila kepribadian dipenuhi oleh nilai agama, maka akan terhindarlah siswa dari kelakukan-kelakuan yang tidak baik. Selain itu juga perhatian orang tua terhadap anak dapat membantu siswa untuk dapat menunjukkan parilaku yang positif. Dan sebaliknya, kurangnya perhatian orang tua terhadap anak dapat berdampak pada siswa yang dapat menimbulkan masalah, karena mereka bebas melakukan semua perilaku negatif yang dianggapnya benar (Hidayat, 2019). Wawancara peneliti dengan guru BK yang memberikan keterangan sebagai berikut:

"Pelaksanaan konseling yang saya lakukan memang tidak bisa tanpa melibatkan bantuan orang lain, terutama orang tua siswa yang sedang memiliki permasalahan, oleh karena itu saya selalu berusaha melibatkan partisipasi orang tua dalam menyelesaikan permasalahan siswa, meskipun tidak semua orang tua 
siswa mau dan bisa ikut terlibat dan berpartisipasi dalam membimbing anakanaknya apalagi jika siswa hanya dianggap menghadapi masalah yang sepele yang bisa diselesaikan disekolah, misalnya seperti membolos”(Ilma, 2021).

Keluarga yang kurang menanamkan pendidikan siswa sejek kecil, sehingga mereka tidak dapat memahami norma-norma yang berlaku dalam masyarakat. Kebiasaankebiasaan yang baik yang sesuai dengan ajaran agama tidak dicontohkan siswa kepada siswa sejak kecil. Kebiasaan-kebiasaan yang baik yang dibentuk sejak lahir akan menjadi dasar pokok dalam pembentukan kepribadian siswa (Zulhaini, 2014).

2. Kurangnya Partisipasi antar Guru dengan Siswa

Tujuan konseling multikultur yang telah ditentukan antara lain membantu individu dalam mewujudkan dirinya menjadi manusia seutuhnya agar mencapai kebahagiaan hidup. Selain itu, tujuan konseling yang diberikan adalah membantu individu untuk mengatasi masalah, membantu individu mengembangkan situasi yang baik, membantu individu mencegah timbulnya problem, membantu individu memahami tata cara hidup bermasyarakat dan lain-lain (Hanum, dkk., 2015). Wawancara peneliti dengan guru Bk yaitu sebagai berikut:

"Pelaksanaan konseling di SMP Negeri 8 Rejang Lebong saya lakukan tidak hanya bekerjasama dengan orang tua siswa tetapi juga melakukan kerja sama dengan para guru dan juga wali kelas, karena para guru yang melihat langsung perilaku dan tindakan para siswa ketika disekolah, oleh karena itu kerjasama dengan guru selalu saya lakukan, meskipun dalam melakukan kerjasama ini tidak semua guru selalu melakukan kerjasama (Ilma, 2021).

Konseling multikultur yang diterapkan di sekolah pada dasarnya untuk membimbing perubahan perilaku atau pola kehidupan sehari-hari, baik di sekolah, di lingkungan bermain, di lingkungan keluarga, dan dimasyarakat (Hastuti \& Marheni, 2017). Pemberian bantuan juga diberikan untuk mengatasi masalah-masalah pribadi, sosial, pendidikan yang dirasakan siswa dari lintas budaya, oleh karena itu untuk melaksanakan konseling guru BK tidak bisa lepas dari bantuan para guru yang terlibat langsung dengan siswa.

3. Adanya Perbedaan Budaya pada Siswa

Multikulturalisme merupakan sebuah paham yang menekankan pada kesederajatan dan kesetaraan budaya-budaya lokal tanpa mengabaikan hak-hak dan eksistensi budaya lain (Rahim, 2012). Hal ini sangat penting dipahami bersama dalam kehidupan 
masyarakat yang multikultural khususnya pada kalangan siswa, sebab bagaimana pun setiap lingkungan sekolah memiliki keragaman bahasa sosial, agama, budaya dan sebagainya. Keragaman tersebut amat kondusif bagi munculnya konflik dalam berbagai dimensi kehidupan (Fadila, dkk., 2020). Adanya perbedaan budaya pada siswa mengakibatkan permasalahan bagi guru BK dalam melaksanakan konseling multikultural, dalam wawancara ia memberikan informasi sebagai berikut:

"Siswa di SMP Negeri 8 Rejang Lebong bukan berasal dari budaya yang sama, berbagai budaya dan karakter siswa yang ada mengakibatkan perbedaan perilaku pada siswa, sehingga mengharuskan saya memiliki cara tertentu untuk melaksanakan konseling, saya harus benar-benar memahami perbedaan budaya mereka, misalnya siswa yang memiliki kebiasaan tempramen, maka saya harus melakukan konseling dengan sikap yang lemah lembut dan tidak marah (Sari, 2021).

Pengaruh pergaulan bagi siswa selalu menjadi langkah pertama dalam melakukan suatu kegiatan dan bentuk kenakalan, melalui pergaulan inilah mereka dapat pengalaman dimana pengalaman ini biasanya dipraktekkan dalam bentuk perbuatan dan kelakuan, sementara apa yang dilakukan itu ada yang melanggar aturan, etika dan moral dan ini tidak di sadari, karena bagi siswa belum dapat memahami terhadap akibat yang akan ditimbulkan, baik bagi dirinya saat sekarang maupun terhadap masa depannya (Patinus, 2014).

Kebergaman budaya melahirkan segala dinamika berupa sikap, respon, serta tingkah laku dan terkadang kedinamisan itu tidak dapat diterima oleh pihak lain sehingga menyebabkan gesekan-gesekan yang berujung pada permasalahan. Persoalan-persoalan tersebut membutuhkan pengkajian dan penyelesaian berdasarkan pendekatan keilmuan seperti bidang keilmuan konseling yang berbasis keagamaan. Selanjutnya, masih wawancara peneliti dengan guru BK yang memberikan keterangan sebagai berikut:

"Budaya siswa yang berbeda juga terlihat dari adanya perbedaan sikap dan perilaku yang saling mempengaruhi, seperti siswa yang memiliki budaya kurang baik misalnya terbiasa berbicara kasar, kotor dan juga tidak sopan, budaya ini biasanya lebih banyak ditiru oleh siswa lain dengan alasan gaya bicara yang lebih gaul dan modern, oleh karena itu sebagai guru BK tantangan saya yaitu merubah budaya tersebut dengan menerapkan budaya yang sesuai dengan tatanan yang ada dan tepat untuk mereka” (Ilma, 2021). 


\section{Upaya Konselor Menangani Problematika Konseling Multuluktural}

Bimbingan konseling dalam Islam merupakan serapan dari kata konseling secara umum yakni bimbingan konseling yang teori-teorinya berdasarkan pemikiran manusia melalui hasil eksperimen sedang Bimbingan konseling Islam adalah juga hasil karya manusia namun berlandaskan kepada kitab suci (Al-Qur'an dan Hadits) (Awad, 2015) Layanan bimbingan konseling harus bertolak dari masalah yang sedang di hadapi oleh klien, konselor hendaknya tidak terperangkap dalam masalah-masalah lain yang tidak dikeluhkan oleh klien (Hidayat, dkk., 2019). Bimbingan multikultural diartikan sebagai upaya menunjukan jalan memimpin, menuntun, memberi petunjuk, mengatur mengarahkan dan memberi nasehat kepada siswa dari multikultural

\section{Meningkatkan Pelaksanaan Konseling Multikultural}

Pelayanan bimbingan dan konseling yang multikultur adalah terwujudnya kehidupan kemanusiaan yang membahagiakan melalui tersedianya pelayanan bantuan dalam pemberian dukungan perkembangan dan pengentasan masalah agar peserta didik dari berbagai etnis, budaya, dan agama dapat berkembang secara optimal, mandiri, dan bahagia (Firdaus, dkk., 2015). Secara kongkrit konseling multikultural dilakukan dengan berbagai cara, seperti yang dijelaskan oleh guru BK yaitu sebagai berikut:

\section{"Langkah kongkrit yang saya lakukan untuk memaksimalkan pelaksanaan} konseling multikultural yaitu saya melakukan konseling kelompok dan konseling individu, karena disekolah saya belum memiliki jam tatap muka dikelas jadi melaksanakan konseling individu atau bimbingan kelompok saya rasa yang paling efektif untuk dilakukan" (Sari, 2021).

Melalui upaya memaksimalkan konseling multikultural maka dapat memberikan dukungan perkembangan dan pengentasan masalah bertujuan agar peserta didik yang beragam dapat berkembang secara optimal, mandiri dan bahagia baik dalam arti lahir maupun batin (Hidayat, dkk., 2019).

\section{Meningkatkan Kerjasama dengan Guru dan Orangtua}

Meskipun dengan siswa yang beragam sudah menggunakan sistem informasi yang canggih, selalu menanamkan budaya etika yang diimplementasikan melalui kerjasama dengan seluruh komponen sekolah, baik guru dan orang tua siswa. Mengenai kerjasama ini guru BK memberikan keterangan sebagai berikut:

"Pelaksanaan konseling multikultural tidak bisa saya lakukan sendiri, saya harus menjalin kerja sama dengan komponen sekolah baik itu dengan kepala sekolah, 
dengan guru yang mengajar serta dengan orang tua yang terlibat langsung dengan siswa, karena komponen-komponen tersebut ikut mendukung dan mempengaruhi keberhasilan konseling ini, oleh karena itu mereka selalu saya libatkan" (Ilma, 2021).

Adanya komitmen atau kesepakatan antara seluruh pihak yang terlibat dalam dunia pendidikan memfasilitasi siswa dalam pelaksanaan konseling multikultural sehingga siswa memperoleh layanan pendidikan yang paling prima, selain itu pihak sekolah juga harus menyusun tata tertib atau peraturan tata krama berkomuniksi dalam konseling mutikultural yang disepakati bersama oleh komunitas sekolah (Dagong, 2019). Kerjasama guru BK dengan para guru dalam memaksimalkan kegiatan konseling multikultural juga dijelaskan oleh guru BK sebagai berikut:

"Bentuk kerjasama yang saya lakukan dengan guru kelas dalam konseling multikultural salah satunya jika ada siswa yang melanggar tata tertib di kelas seperti bermain HP di kelas, berkelahi di kelas, maka saya meminta bantuan kepada guru kelas untuk memberikan nasehat, memberikan teguran, peringatan sekaligus memberikan laporan kepada saya sehingga saya bisa melakukan konseling individu terhadap siswa yang bermasalah, karena disini siswa yang bemasalah kurang terbuka menyampaikan permasalahannya (Sari, 2021).

Pemberian layanan konseling pada jenjang pendidikan menengah yang selama ini diterapkan lebih menekankan bimbingan bersosialisasi, berinteraksi, berkarir, dan berkomunikasi antar siswa. Berbagai realitas yang diharapkan dalam pemberian layanan konseling di sekolah hendaknya merupakan layanan sosial yang bersifat humanis yang bertujuan membantu siswa yang beragam ini dalam mengatasi masalah di sekolah pada khususnya dan masalah di dalam keluarga atau masyarakat pada umumnya. Kerjasama guru BK dengan salah satu orang tua siswa juga dilaksanakan dengan baik (Hanum, dkk., 2015). 3. Memanfaatkan Media dalam Konseling Multikultural

Salah satu upaya dalam pelaksanaan konseling multikultural yaitu dengan memanfaatkan berbagai media yang ada. Media BK merupakan seluruh media yang dapat membantu guru BK dalam melaksanakan tugas sehari-hari baik menjadi tidak bergerak maupun bergerak, baik media manual maupun elektronik, baik media berbasis benda nyata maupun berbasis IT, baik media sederhana maupun canggih. Mengenai hal ini, guru BK memberikan keterangan sebagai berikut: 
"Konseling multikultural yang saya lakukan menggunakan media yaitu salah satunya media telepon ataupun media WA, jika sedang memberikan saran atau nasehat kepada siswa yang memiliki masalah pribadi tetapi belum maksimal di selesaikan disekolah, maka saya melakukan bimbingan individu dengan menggunakan media telepon, saya menelpon siswa yang bersangkutan sehingga siswa lebih terbuka, tidak merasa malu dalam menceritakan permasalahannya, hal ini memberikan kemudahan juga bagi siswa untuk lebih terbuka dan jujur" (Ilma, 2021).

4. Memberikan Bimbingan Nilai-Nilai Karakter Berdasarkan Agama

Karakter merupakan nilai-nilai perilaku manusia yang berhubungan dengan Tuhan Yang Maha Esa, diri sendiri, sesama manusia, lingkungan, dan kebangsaan yang terwujud dalam pikiran, sikap, perasaan, perkataan dan perbuatan berdasarkan norma-norma agama, hukum, tata krama, budaya dan adat istiadat (Fiah, 2014).

Individu yang memiliki karakter baik adalah individu yang bisa membuat keputusan dan mempertanggung jawabkan setiap akibat dari apa yang diperbuat. Dalam hal ini guru BK menjelaskan sebagai berikut:

"Salah satu upaya yang saya lakukan untuk membimbing nilai-nilai karakter berdasarkan agama kepada siswa yaitu melalui contoh-contoh yang positif baik dari sikap, perilaku dan perbuatan yang berhubungan dengan karakter, misalnya seperti bagaimana bersikap dengan teman tanpa harus meniru contoh-contoh yang negatif yang tidak sesuai dengan kaidah ajaran agama kita” (Sari, 2021).

Bimbingan nilai-nilai karakter juga dapat dilihat dari keteladanan sikap, perbuatan yang menunjukkan nilai-nilai karakter yang sesuai dengan ajaran agama Islam, hal ini dilakukannya melalui sikap, prilaku dan perbuatan yang baik dilingkungan keluarga maupun di lingkungan masyarakat.

\section{KESIMPULAN}

Berdasarkan pembahasan yang telah diuraikan diatas, maka dapat disimpulkan bahwa:

1. Bentuk Problema Konseling Multikultural di di SMP Negeri 8 Rejang Lebong adalah konselor harus benar-benar sesuai dengan budaya konseli karena realitas lingkungan siswa yang beragam menjadi problem bagi konselor sehingga konselor harus benarbenar memahami berbagai macam budaya yang dimiliki oleh siswa. 
2. Kendala-Kendala dalam Melaksanakan Konseling Multikultural pada Siswa SMP Negeri 8 Rejang Lebong diantaranya yaitu masih kurangnya kerjasama orang tua terhadap siswa yang bermasalah, kurangnya partisipasi antar guru dengan siswa, adanya perbedaan budaya pada siswa yang mengharuskan guru BK memahami budayabudaya siswa yang berbeda-beda tersebut.

3. Upaya Konselor dalam Menangani Problematika Konseling Multikultural di SMP Negeri 8 Rejang Lebong dilakukan dengan cara meningkatkan pelaksanaan konseling multikultural, meningkatkan kerjasama dengan guru dan orangtua, memanfaatkan media dalam konseling multikultural dan memberikan bimbingan nilai-nilai karakter berdasarkan agama.

\section{DAFTAR RUJUKAN}

Awad, F.B. 2015. Konseling Islam dalam Masyarakat Multikultural, Zawiyah: Jurnal Pemikiran Islam, 1(1), 175-194.

Dagong, S.W. 2019. Kompetensi Pendidik Dan Tenaga Kependidikan Dalam Meningkatkan Mutu Pendidikan Smp Negeri 3 Kwandang, Al-Idarah: Jurnal Pendidikan Islam, 9(4), 204-213.

Elizar, E. 2018. Urgensi Konseling Multikultural Di Sekolah. Edukasi Lingua Sastra, 16(2), $13-22$.

Fadila, F., Beni, A., Hartini. 2020. Counseling Service in Overcoming Faith and Morality Issues for Inmates Child. Jurnal Konseling dan Pendidikan, 8(3), 234-237.

Fiah, R.E. 2014. Peran Konselor Dalam Pendidikan Karakter. Jurnal Bimbingan dan Konseling, 1(1), 35-46.

Firdaus, Faishal, Y., Dian, K.A. 2015. Penanaman Nilai-Nilai Multikulturalisme Melalui Pendidikan Untuk Menyiasati Masalah Multikultur Di Indonesia \& Malaysia. ASEAN Comparative Education Research Network Conference, 1(1), 1756-1767.

Hanum, M., Prayitno, Nirwana, H. 2015. Efektifitas Layanan KonselingPerorangan Meningkatkan Kemandirian Siswa Dalam Menyelesaikan Masalah Belajar. Konselor, 4(3), 162-168.

Hartini. 2017. Perkembangan Fisik Dan Body Image Remaja. Islamic Counseling: Jurnal Bimbingan Konseling Islam, 1(2), 27-54.

Hastuti, M.M.S. \& Marheni, A.K.I. 2017. Kompetensi Konseling Multikultur Bagi Konselor Sekolah: Suatu Kajian Teoretis. Proceeding Seminar Dan Lokakarya Nasional Bimbingan Dan Konseling, 1(1), 93-109.

Hidayat, R., Beni, A., Hendra, H., Sumarto, Deri Wanto, and Mirzon Daheri. Sindang Jati Multikultural Dalam Bingkai Moderasi. Bengkulu: Buku Literasiologi.

Lubis, A., Yessy, E., Vira, A. 2017. Bimbingan Kelompok Dengan Teknik Sosiodrama Meningkatkan Regulasi Emosi Pada Siswa Sma Di Kota Bengkulu. Consilia: Jurnal Ilmiah Bimbingan dan Konseling, 1(1): 43-51.

Patinus. 2014. Kenakalan Remaja Di Kalangan Siswa-Siswi Smpn 07 Sengah Temila Kecamatan Sengah Temila Kabupaten Landak. Jurnal Tesis PMIS-UNTAN-PSS2014, 1(1), 1-15. 
Rahim, R. Signifikansi Pendidikan Multikultural Terhadap Kelompok Minoritas. Analisis, 12(1), 161-182.

Wibowo, M.E. 2015. Aktualisasi Bimbingan Dan Konseling Pada Pendidikan Dasar Menuju Peserta Didik Yang Berkarakter. Prosiding Seminar Nasional dan Call For Papers, 2(1), 323-332.

Winarlin, R., Lasan, B.B., Widada. Efektivitas Teknik Sosiodrama Melalui Bimbingan Kelompok Untuk Mengurangi Perilaku Agresif Verbal Siswa SMP. Jurnal Kajian Bimbingan dan Konseling, 1(2), 68-73.

Zulhaini. 2019. Peranan Keluarga Dalam Menanamkan Nilai-Nilai Pendidikan Agama Islam Kepada Anak. Al-Hikmah, 1(1), 1-15. 